\title{
History of Medicine in Jagodina District
}

\author{
Marko Jeremić ${ }^{1}$, Ana Vuković2 ${ }^{2}$ Ninoslav Stanojlović3 ${ }^{3}$ Rade Vukovićc ${ }^{4}$ Dejan Marković ${ }^{2}$ \\ 'Department of Dentistry, Health Care Center, Jagodina, Serbia; \\ ${ }^{2}$ University of Belgrade, School of Dental Medicine, Department of Pediatric and Preventive Dentistry, Belgrade, Serbia; \\ 3Primary School "October 17"th", Jagodina, Serbia; \\ "Institute for Mother and Child Health Care of Serbia "Dr Vukan Čupić", Belgrade, Serbia
}

\begin{abstract}
SUMMARY
The first record of scientific medicine in Serbia has been found in the early of $12^{\text {th }}$ century. For centuries lifestyle, nutrition, natural environment, armies passing through, cultural heritage, and prejudice have affected healthcare in Serbia. Until 1820, Serbia has not had any educated doctor. Fourteen district physicians from 1839 and Dr. Karlo Beloni, to the last one, Dr. Selimir Djordjević - have spent part of their professional careers in Jagodina. All of them have had influence on raising health culture of Jagodina and its population and helped to overcome easily and quickly all existing diseases and epidemics. The Jagodina Hospital has been working without interruption for 147 years and represents one of the oldest healthcare institutions in Serbia.
\end{abstract}

Keywords: health care centre; community medical service; history of medicine; development

True men of science revere the past. Everything we do and everything we are is the result of a hundred year's labor.

Ernest Renan (1823-1892)

\section{INTRODUCTION}

Since creation of mankind, the history of medicine has been studying the origin and development of diseases and their treatment. The history and origin of medicine is an outcome of human instincts to protect and defend its species. Along with scientific medicine, animistic or magical medicine has developed with spiritual character that was built on the belief that cure exists in nature, spirits, plants, animals and objects. Religious medicine interpreted diseases as the consequence of evil spirits who were undermining the existing balance in the body. Apocryphal medicine, found in indigenous peoples of Balkan by the Slavs, was a mixture of various oriental and ancient cults, as well as philosophical systems of the Ancient history. Church has not recognized it for its nature and belief in negative effects of the evil forces of nature. The treatments consisted of prayers and divinations [1].

The present study is a descriptive research of development of medicine in Serbia and Jagodina district. We observed development of medicine from the medieval period until nowadays. Methods used were: documentation analysis and desk research of secondary information. Furthermore, historical data were gathered through interviews and analyzed.

\section{DEVELOPMENT OF MEDICINE DURING MEDIEVAL PERIOD}

The first record of the existence of scientific medicine in Serbia comes from the early of $12^{\text {th }}$ century, representing the medicine of Hippocrates, Galen, Aristide and other ancient physicians, just like European medicine. It was on the rise between the $12^{\text {th }}$ and $15^{\text {th }}$ century. Purveyors of medical knowledge from Byzantium to Serbia were mostly monks in Serbian or Byzantine colonies in Athos, Sinai and Jerusalem, while western medicine was passed on by doctors and pharmacists trained in western medical schools. The founders of first hospitals were Stefan Nemanja and St. Sava in Hilandar Monastery in 1191. St. Sava in Studenica founded the first hospital in Serbia in 1208. He later founded a few more (Ravanica, Visoki Dečani), all of which operated until the downfall of Serbian medieval states [2]. However, scientific medicine of the medieval Serbia was cut in its further development, it was stagnating more and more, and at the end of the $17^{\text {th }}$ century it was reduced to traditional medicine and, to a certain extent, to the religious one.

Healthcare situation of Serbian people was affected by various factors, such as lifestyle, nutrition, natural environment, armies passing through, cultural heritage, and prejudice. The treatments were primitive; hence, people in larger towns would turn for a cure to traditional doctors: berbers - the Turks: they let blood out by horns and leeches, pooled teeth out and performed minor surgeries; hakims - the Greeks, originally from Epirus, residing in certain cities, also called kaloyatri ("good doctors"), who had family inheritance of medical knowledge; self-taught 
doctors - ethnic Greeks, Serbs or Turks; and folk healers (men and women) - Greeks, Jews and Roma, passing on their skills from generation to generation [3].

Outside major towns, in villages, people were treated in monasteries by the monks who knew the secret of medicinal herbs treatment from medical books, the content of which they occasionally revised and extended, while the priests treated patients with prayer, i.e. by reading and drawing a cross onto the affected area. Traditional physicians, found in almost every village, would treat people using plants, ointments, medicinal herbs and chanting. These were mostly older women who had stopped giving birth and who were trained in preparing these cures. They would pass on their knowledge to younger female family members (until the age of 12).

Quackery did not exist in its usual sense, since there were no educated doctors. In stores in larger towns people were able to buy all known drugs, some of which were toxic and sold without control. Measures to suppress quackery were carried out in the 1830 s, but, for a very long time, people were not able to get rid of superstition and ingrained convictions.

\section{DEVELOPMENT OF MEDICINE DURING THE UPRISINGS}

During the centuries of Turkish reign, Serbia was underdeveloped in every cultural aspect. It had no doctors, not only during the Uprisings, but years and years later as well. The lack of enlightenment among people, Turkish lootings and men losses in the Uprisings did not provide cultural and material conditions for foreign doctors to come and work in the country. The first doctors, who were visiting Serbia rarely and autonomously, would come as personal doctors of the Belgrade's Pasha and, later on, in the service of the Prince and his court. Subsequently, those doctors entered the military service as military doctors in the army that had just began to form [1].

With the beginning of struggle for national liberation, Serbia started paying more attention to organizing its healthcare system. During the First and Second Serbian Uprisings, the wounded soldiers were treated in monasteries or at their homes. Karadjordje's government built two hospitals in Serbia - one in Belgrade and the other one in Šabac by the end of their ruling. The doctors were mostly foreign physicians and few physicians from Vojvodina who joined military and civil service. This was a period when Serbia - as a country where young intellectuals were coming after their studies abroad - was trying to change its conservative and patriarchal way of life [4].

In the early decades of the $19^{\text {th }}$ century, Serbia was still an incompletely formed part of the Ottoman Empire, without trained local personnel, poor and underdeveloped in all aspects. Centuries of Turkish govern in Serbia prevented any cultural and medical development [5].

\section{DEVELOPMENT OF MEDICINE IN LIBERATED SERBIA}

Until 1820, there were no educated doctors in Serbia. The first graduated doctor was Constantin Alexandridi, the second was Dr. Vito Romita, whose compatriot, Dr. Bartolomeo Silvestar Kunibert, accepted Dr. Romita's invitation to come to Serbia in 1826 as the third educated doctor, where he worked as Prince's personal doctor until 1839 [6].

The first Serbian doctor in Prince's Serbia was Dr. Jovan Stejić. He was born in Arad in 1803 and obtained his $\mathrm{PhD}$ in Vienna in 1829 with the help of Jevrem Obrenović. He moved to Serbia to work with Jevrem, but not long after Prince Miloš engaged him as his personal doctor and a mentor to his sons, Milan and Mihailo. Due to disagreements with Prince Miloš, Dr. Stejić moved to Zemun, which was outside Serbian borders at that time. When the prince left Serbia in 1840, Dr. Stejić returned to Belgrade and together with Dr. Karlo Pacek formed the Serbian Civil Ambulance. In 1845, he was appointed as the State Soviet Secretary of the highest administrative and political body, where he remained until his death in 1853 [7]. Apart from them, there were other doctors working in Serbia as foreigners until 1839:

- Dr. Nestor Mesarović from Irig, who was Prince’s physician in Kragujevac

- Dr. Karlo Pacek from Budapest, a great friend and advisor to the Obrenović dynasty who had a very important role in the formation of healthcare service in Serbia

- Dr. Djordje Pantelić, the Prince's family doctor in Požarevac, and later the Guard's military doctor

- Dr. Maksim Nikolić-Miškovičev from Sremski Karlovci, a military doctor

- Dr. Emmerich Lindenmaier from Banat, the first Military Medical Department Chief and Chief of the military and civil healthcare services

- Dr. Josip Rabrić from Sremski Karlovci, a quarantine physician in Aleksinac and Kragujevac

- Dr. Herman Mainert from the Czech Republic, who arrived in Serbia in 1836 [1].

\section{DEVELOPMENT OF MEDICINE IN JAGODINA AFTER THE LIBERATION FROM TURKS}

The first hastily trained doctor came to Jagodina after the Second Serbian Uprising. According to the letter of Janićije Radović, a head of Jagodina's mezulhana (a kind of post office and tavern for couriers, where they would switch horses and continue their way to Istanbul or Pest) addressed to Prince Miloš in 1824, there was a certain fellow named Guido, an Italian, who travelled through the Balkan region on his way to Istanbul, and he was accompanied by Tristan, the pharmacist, and Peter, his companion who spoke Turkish besides Italian [8].

In 1829, a historian and itinerary writer Oto Dubislav Pirh in his book A travel through Serbia in 1829 mentioned only six doctors, one of which, Djordje Novaković or Leo- 
nid Ehrlich, lived in Jagodina. He was a Christianized Jew, born in Poland, a doctor in the Austrian army, from where he transferred to Šabac. One of the first surgeons in Serbia and Jagodina had been working there since 1826 [9]. In the $18^{\text {th }}$ and $19^{\text {th }}$ centuries, a great part of Europe was under the outbreak of various diseases that spread to Serbia from Turkey. In 1830s, frequent infections and risk of epidemic pervasion across the borders led to the formation of quarantine stations at major border crossings, as well as to setups of the medical and police border cordons. The most dangerous were cholera and plague epidemics, which had repeatedly affected the population of Serbia of that time [3]. During the last plague outbreak on Serbian and European territory, which came from Turkey in 1837, Jagodina was most severely affected, as it was the center of infection. Dr. Karlo Nadj from Zemun's quarantine was invited as the leading expert, while his advisors were Dr. Pacek, Dr. Lindenmaier and Dr. Kunibert. Prince Milos fully authorized Dr. Karlo Nadj and sent him to Jagodina. The plague was stopped in three and a half months.

On April 17 1839, the Ministry of Internal Affairs with the Medical Department, which governed medical professions in founding (doctors, district physicuses, pharmacies and pharmacists, hospitals and midwives), proposed appointing one doctor to every district in Serbia: medical doctors to Šabac, Belgrade, Smederevo, Jagodina, Čačak and Užice; surgeons to Valjevo, Belgrade, Milanovac, Zaječar, Soko Banja, Kruševac and Kraljevo; existing military doctors to Kragujevac and Pozarevac. On July 24, 1839, by the order of Djordje Protić, the Minister of Internal Affairs, and Dr. Karlo Pacek, the Interim Chief of the Principality of Serbia's Medical Department, medical centers were established in the country and district physicuses were appointed in Šabac, Belgrade, Smederevo, Jagodina, Čačak and Užice, and surgeons in Valjevo, Belgrade, Milanovac, Zaječar, Banja, Knjaževac and Kraljevo, while military doctors were sent to Kragujevac and Požarevac since Prince's Guard units resided there.

Following Dr. Pacek's instructions, the district physicuses' task was to vaccinate the population, prevent the use of unhealthy food and beverages, prevent quackery, monitor the trade in medicaments, teach people about hygiene habits, perform medical and court tasks (perform medical examinations and give opinions on a person's ability to work and be married, or on murdered, poisoned and beaten persons), perform autopsies and necessary veterinary tasks to prevent disease spreading among animals. Purely medical activities were as follows: medical examination of the sick persons; giving opinions on the ability of an individual to have a particular profession, especially civil service, and the ability to marry; expertise in cases of murder, poisoning and fights; individual treatment and treatment in hospitals; issuance of drugs from pharmacy kits in places where public pharmacies did not exist; and submitting work reports. At the same time, in the absence of county or village doctors, they needed to treat the sick in their homes and hospitals, as well as to carry drugs in pharmacy kits if a pharmacy did not exist in their towns.

Important healthcare legal acts were brought before physicuses were appointed to counties. The first one, dat- ing from July 81839 , was on the obligation of vaccination against chickenpox with a detailed description of all doctor's procedures [10].

Lindenmaier's list of doctors and medical staff from 1839 contains as follows:

1. Dr. Pacek - court and personal Prince's doctor

2. Dr. Nikolić Mišković - Prince’s family court doctor

3. Dr. Emerich Lindenmaier - Guard's doctor in Kragujevac

4. Dr. Karlo Beloni - command doctor in Čačak

5. Dr. Rebrić - private doctor in Belgrade

6. Dr. Mainert - Guard's doctor in Belgrade

7. Dr. Mušicki - quarantine doctor in Aleksinac

8. Dr. Mihajlović - quarantine doctor in Svilajnac

9. Dr. Slavuj - Master of Surgery and Guard's second doctor in Belgrade

10. Dr. Djordje Novaković - surgeon

11. Dimitrije Kaparis - in the Guard in Požarevac, but without official diploma

12. Sava Jovanović - in quarantine

13. Mata Ivanović - private pharmacist in Belgrade

14. Pavle Ilić - court pharmacist and Guard's pharmacist in Kragujevac

15. Dr. Šteker - doctor of Turkish garrison in Belgrade Fortress

16. Dr. Florian Birg - Master of Surgery, the second doctor of Turkish garrison and pharmacist of Turkish hospital [11].

It is believed that Dr. Karlo Pacek and Dr. Jovan Stejić composed the rules of work of future physicuses, modeled after the Austro-Hungarian regulation on engrafting cowpox. In 1842, the Law on Compulsory Vaccination was extended and amended and was even stricter. A written certificate of vaccination was requirement for a person to enter into marriage, receive scholarship to continue one's education or perform public service (police, education and clergy). The "Rules of Work for Future Physicuses" or the "Instructions for District Doctors and Physicuses" were adopted on August 21, 1839. This rulebook consisted of 23 articles and represented the first Medical Department's law [10].

\section{DEVELOPMENT OF ORGANIZED HEALTHCARE SYSTEM IN JAGODINA IN THE $19^{\text {TH }}$ CENTURY}

Dr. Karlo Beloni was appointed as the second district physicus of Jagodina (Figure 1), who, until that moment, was the Guard's doctor and the doctor of Moravian command in Čačak, where he served for four and a half years for the annual salary of 300 thalers [12]. In 1839, the Jagodina District, where Dr. Beloni was sent to as only doctor, had 6,674 households: 3,471 in the County of Temnik, 3,155 in the County of Levac, and 546 in Jagodina and its surroundings. During his stay in Jagodina District, Dr. Beloni was submitting monthly work reports to his superiors. Dr. Beloni was born in 1812 in the village of Levica at the Hungarian territory Barš Marmedja. He came from a Catholic family. He graduated from the University of Pest with the title of Doctor of Medicine and Master of 


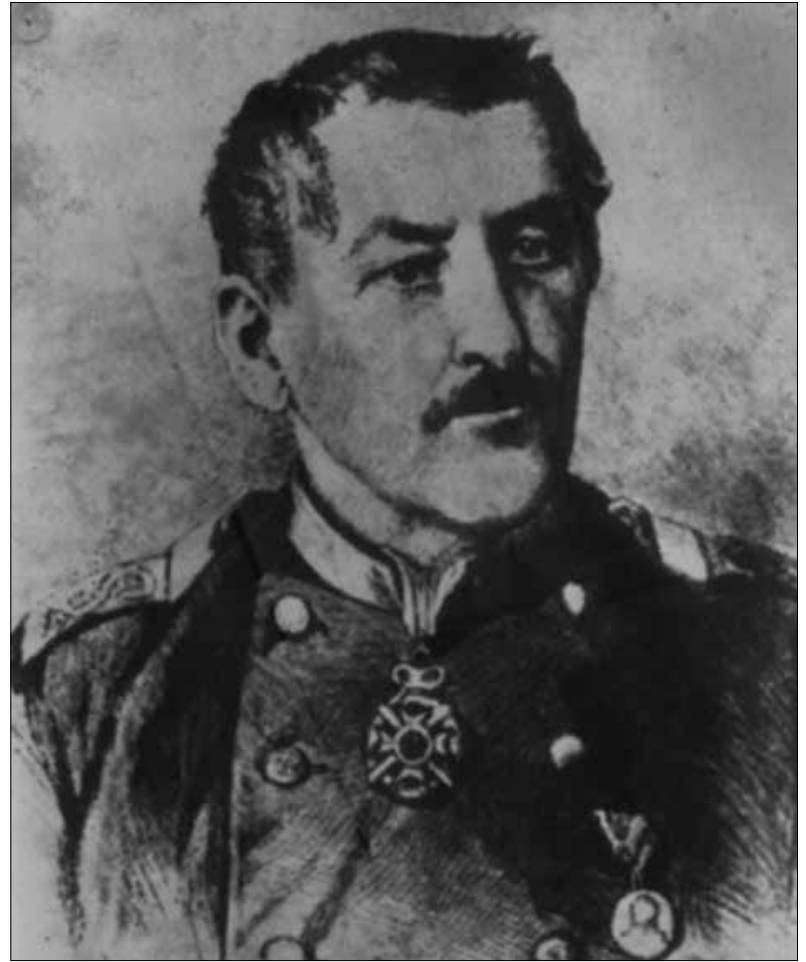

Figure 1. Dr. Karlo Beloni

Slika 1. Dr Karlo Beloni

Ophthalmology and Obstetrics (midwifery). However, he practiced medicine when he moved to Serbia during 4 years and 7 months. Most of this period ( 3 years and 5 months) he spent as a military doctor in Čačak, Karanovac, Belgrade, Kragujevac and Ćuprija. He spoke and wrote Serbian quite well. In his reports, Dr. Beloni stated that, during his visits to patients, he came across good general health of people and livestock, that there were no severe epidemics and that the patients asked for help "moderately". The patients mostly complained of catarrhal and rheumatic inflammations, as well as fever, liver inflammation and rheumatism. There were no diseases in cattle, except rabies, which was, in his opinion, a result of severe winters. However, the district chief emphasized that Dr. Beloni faced a series of difficulties on the field, which were a consequence of people's ignorance of health in general, thus the patients ran away from his services even at the risk of punishment from the authorities. Otherwise, he aspired to accurately perform police and medical duties, particularly when examining the deceased, and to be diligent in grafting cowpox, but parents were still reluctant to vaccinate their children.

Regarding the issuance of certificates, he tended to be precautious, impartial and truthful. He carried a sizeable pharmacy kit that contained all needed drugs at all times, which he donated to the poor and charged to the wealthy people. He was successful in treating diseases, particularly more serious cases of dysentery and fever, but there was a lack of trust in his work due to people's fear and superstition. In addition, he was gentle, thus he had good relationship with the healthy, and patience with the sick. In the spring of 1841, Dr. Beloni once again took over the general examination of the district's inhabitants, but it ended without visible results. He went in vain three

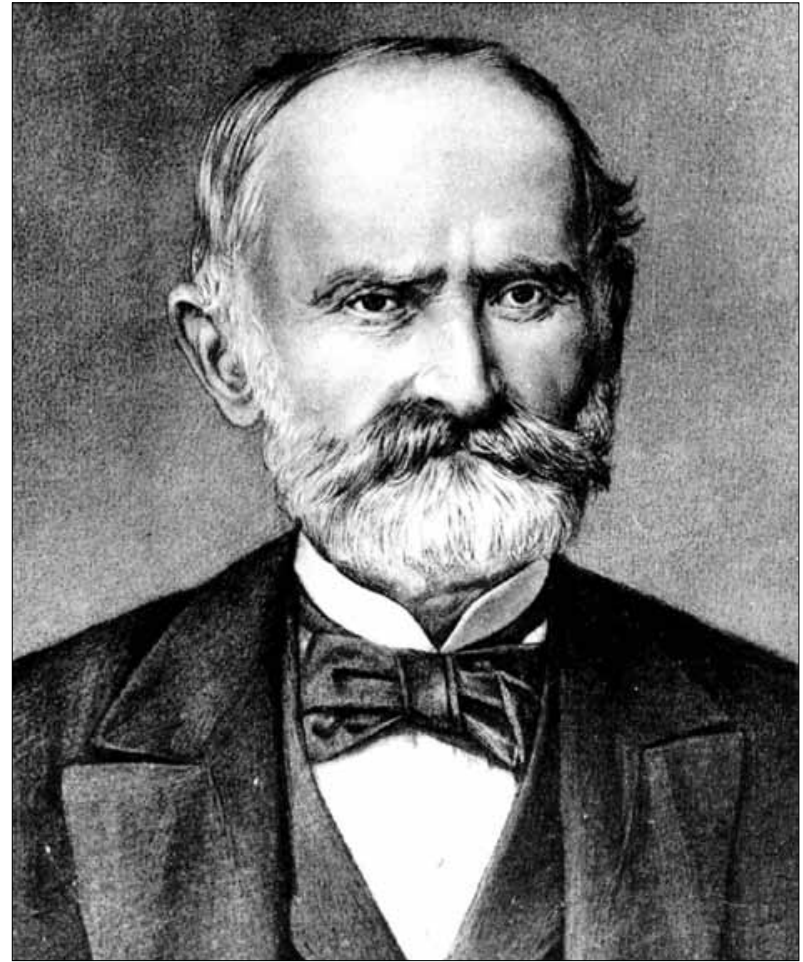

Figure 2. Dr. Josif Pančić Slika 2. Dr Josif Pančić

times to Kavadar, the village in Levac County that suffered from smallpox epidemic, accompanied by the county mayor and the police, but never found sick children in their homes because their parents were hiding them in the woods. Disappointed by such behavior and personal failure, Dr. Beloni requested to be transferred to Čačak district in May 1841. He believed that he would be more useful there because he had received greater confidence of the people there and had much more success in his work during earlier service in that area [10].

While waiting a new physicus to be appointed in Jagodina, periodical treatments were in the hands of physicuses from surrounding areas. Dr. Dimitrije Kaparis, a physicus of Požarevac County, worked on suppressing smallpox epidemic in some villages of Jagodina district starting from December 1841. Gligorije Rybakov performed the duty of county physicus until the beginning of 1844, without formal appointment, but with a permission of Dr. Jovan Stejić, the Head of Medical Department, who replaced Dr. Karlo Pacek in this position.

On January 10, 1844, Dr. Andrej Ivanović was appointed the second county physicus by the decree of Prince Alexandar Karadjordjević. He held this position until 1847, when he resigned and became physicus of Negotin County. He was a physicus in Jagodina for three years and fifteen days. In addition to his regular duties, Dr. Andrej Ivanović requested digging new wells to supply potable water, removing garbage from yards and cleaning them, applying hygienic measures, and cover the town streets with stones (cobblestones). He also performed veterinary tasks and founded the first hospital in Jagodina, which was at the level of a clinic [13].

The third physicus was Dr. Josif Pančić (Figure 2), who came to Jagodina on January 31, 1847, at the invitation of 
Avram Petronijević, the owner of glassworks, because of the epidemic of typhoid among the workers of the factory. He managed to stop the epidemic among workers, as well as among the population of the surrounding villages. Due to his success, the population of Jagodina demanded that Josif Pančić becomes appointed as the county physicus. Dr. Josif Pančić worked notably on health education of the people, especially by writing instructions on prevention and treatment of certain diseases, as well as by verbal advices. He pointed to dietary habits as the cause of many diseases [13].

Simultaneously with the appointment of Josif Pančić in Kragujevac, on November 20,1847, Dr. Djordje Malać was appointed the fourth physicus of Jagodina County. He was originally from Osijek in Slavonia and graduated medicine in Budapest. In addition to treatments, physicuses dedicated a major part of their activities to the continuous efforts in fighting against the underdevelopment, but without much success. In his reports, Dr. Djordje Malać states that Jagodina had district offices, district court, elementary school and an improvised hospital. He also mentions undeveloped streets and yards, lack of potable water, and describes cattle that wandered freely. He wrote that, during 1848 , he treated a total of 280 persons, as well as that certain diseases occurred with the change of seasons. Most patients were glass factory workers in Belica. He said that in Jagodina, but mostly in villages, people turned to witchcrafts and traditional remedies more often. Prohibition of selling toxic substances in commercial shops was not fully complied with, not only in Jagodina, but throughout the entire Principality.

After Dr. Djordje Malać resignation in 1849, Bogomir (Godfried Anton) Šulek from Czech Republic became new district physicus. He graduated medicine from $\mathrm{Vi}$ enna and resided in Jagodina District from March 1851 to June 1852. The next one was Dr. Jovan Valenta, also Czech, who graduated medicine in Prague. He served in the District from August 1852 to September 1852, when Spiridon Jeftimijades came, who was originally from Turkey, and he remained at this position until 1860 [13].

According to the announcement of the Ministry of Internal Affairs of March 8, 1852, the district chiefs - with the help of district physicuses and municipal committees - were given assignments to find a suitable building, with at least two rooms and a kitchen, to equip it with necessary inventory and open as a hospital. The President of the Court of First Instance, Stevan Stevanović, with the clerk Aleksandar Jakovljević and informal help of a group of benefactors, directed the founding of the Jagodina Hospital. Village craftsmen donated 3,761 Groschens and a smallish building equipped with six beds was taken under lease. The hospital was opened in late summer of 1852 . In March 1858, the press released the news that a new building was purchased for the hospital and a few patients were gathered there, however, professional care and reliable incomes was still lacking. In the early 1860 , the district physicus, Dr. Spiridon Jeftimijades, wrote in his report: "the town barely has any hospitals, there is only one little house owned by the County, on the outskirts of the town, near the cemetery, where some crippled people are residing".
In October of the same year (1860), the newly appointed physicus, Dr. Mladen Janković, wrote to the authorities that nobody had visited the "municipal hospital" for the entire month. According to his report from the beginning of the following year, the hospital was in poor condition, unequipped and lacking expert care, thus it resembled more a sanctuary for crippled and weak individuals without caretakers than a healthcare institution [14]. He spent a year and a half at the position of physicus. In 1884 he was elected the Interim Chief of the Medical Department within the Ministry of Interior. He was one of the founders and the President of Serbian Medical Society, where he worked for full eight years (from 1873) [15].

Dr. Mladen Janković was replaced in 1862 by Dr. Milosav Pavlović, the first trained doctor in Moravian region, who remained physicus for 11 years. Dr. Pavlović was born in 1827 in the Dražimirovac village, near Jagodina. He started high school in Belgrade in 1845/46, and graduated medicine in Istanbul. He spent a year in Paris at postgraduate studies. He spoke Turkish, Greek, Russian, and French. In 1860, he worked as a doctor in Raška, and on October 20, 1861 he became the district physicus in Jagodina, with the status of "extraordinary physicus at disposal" at that time [16].

The Law on Hospitals Founding and Organization was adopted in 1865. The Ministry of Interior Affairs sent a request on November 16,1866 to district offices in Drina, Užice, Aleksinac, Timočka Krajina, Smederevo, Valjevo, Jagodina, Rudnik, and Ćuprija districts to find private houses for temporary hospitals or municipal houses for rent for municipal hospitals. The hospital was formed in the house of Avram Petronijević, the Minister of Foreign Affairs and owner of the glass factory in Belica, whose family lived in Jagodina. The house was built in 1833, and rented by Avram's successor from Belgrade.

The District Hospital in Jagodina was founded on November 1, 1867 (Figure 3). Its founder was the district physicus, Dr. Milosav Pavlović. On average, 10-15 patients were treated in this hospital in the summer and 30-35 patients in the winter. Upon its opening, the hospital was named "The District Hospital". After Dr. Milosav Pavlović, the hospital's directors, since its establishment until the end of the $19^{\text {th }}$ century, were as follows: Dr. Leopold Levi, municipal doctor (1873-1874), Dr. Kazimir Staniševski, district physicus (1875-1883), Dr. Franja Ribnikar, municipal doctor (1883-1888), Dr. Stevan Siber, district physicus (1889-1891), Dr. Jovan Danić, district physicus (1891-1892), Dr. Venceslav Steiskal, county doctor (18921893), Dr. Pera Dobri, district physicus (1893-1898), Dr. Zarije Popović, district physicus (1898-1900), Dr. Selimir Djordjević, district physicus (1900-1908), and Dr. Živojin Milenković, county doctor (1908-1914) [17].After joining Jagodina and Ćuprija districts in Moravian District, with the seat in Cuprija, in 1891, the hospital had the function of a district hospital for Belica, Temnik and Levac counties. In 1907, it finally acquired the status of a county hospital, but was brought back to the district level in 1909.

According to the Law on the Regulation of Medical Profession and Preservation of Public Health from 1881, every district and county should have a county doctor 

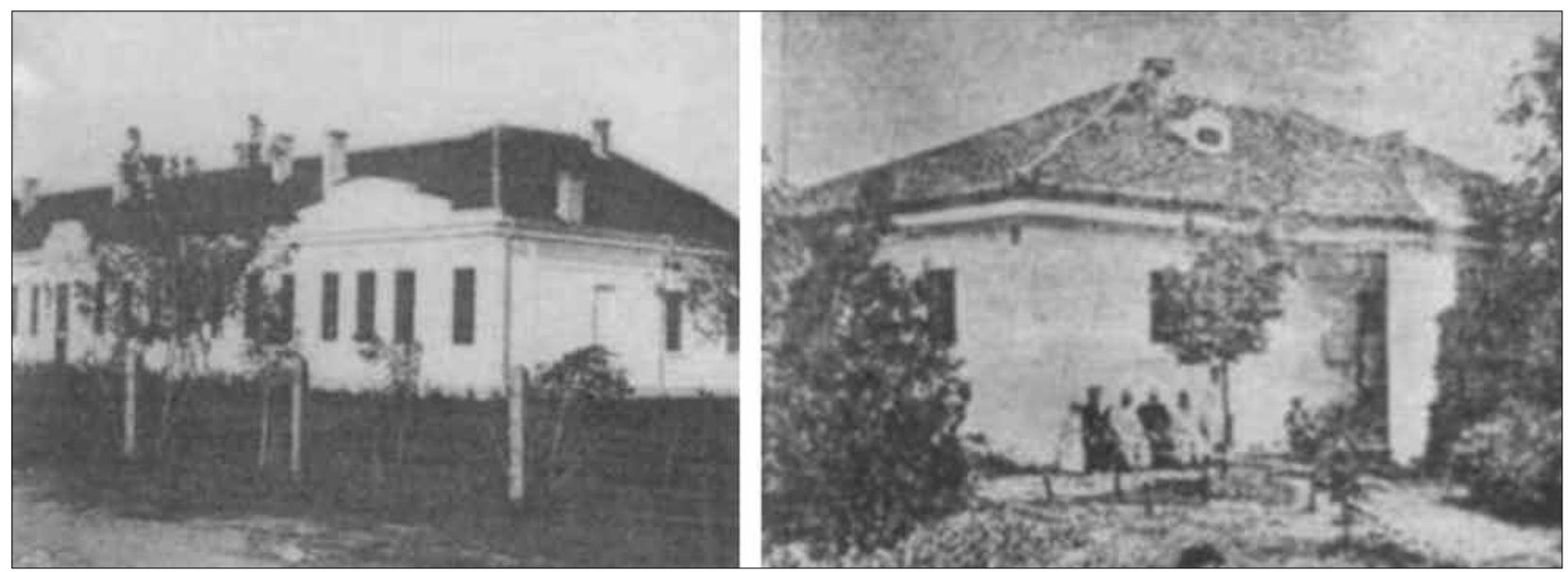

Figure 3. The first hospital in Jagodina

Slika 3. Prva bolnica u Jagodini

with the same qualifications as a physicus. He should be appointed by Prince's decree upon the proposal of the Minister of Interior Affairs, as acting doctor (if Serbian citizen) or contractual one (if foreign citizen). Jagodina District comprised the following three counties at that time: Belica, Levac and Temnik. The doctors in Belica County were: Dr. Josif Vidaković (1890), Dr. Veneslav Steiskal (1891-1892), Dr. Dragoljub Djordjević (1895-1898), Dr. Živojin Milenković (1901-1902), Dr. Kosta Ristić (19031904), Dr. Djordje Hadi (1905) and Dr. Živojin Milenković (1906-1914). The doctors of Levac County were: Dr. Ilija Jovanović (1896), Dr. Dragoljub Djordjević (1897), Dr. Ilija Ivanović (1898-1903), Dr. Vladimir Popović (1907), Dr. Svetislav Šohajević (1908-1910), etc [1].

By the law, each municipality in Serbia with 10,000 inhabitants was obliged to financially support, through the municipal tax, one municipal doctor, who was also a member of the municipal administration. All issues regarding people's health and veterinary tasks could not be solved without his presence. In the event of war, the doctors performed their medical duties at military hospitals.

Municipal doctors in Jagodina were: Dr. Gligorije Ribakov (1835), Dr. Lepold Levi (1875-1879), Dr. Franja Ribnikar (1883-1889), Dr. Gorgije Zinoviev (1889-1890), Dr. Radivoje Vukadinović (1891-1898), Dr. Venceslav Steiskal Sr. (1899-1900), Dr. Vojislav Stefanović (1904), Dr. Svetislav Stefanović (1905) and Dr. Damnjan Tufegdžić (1910-1914) [1]. In 1873 and 1874 there were no physicuses. During the Serbian Turkish war (1876-1878) Jagodina had a district hospital and a town pharmacy. Dr. Kazimir Staniševski was the district physicus and District Hospital Director, while Dr. Franja Ribnikar performed the duty of the municipal doctor. In 1891, Dr. Stevan Siber became a physicus for one year. The eleventh physicus was Dr. Jovan Danić, in 1892 and 1893. The twelfth was Dr. Pera Dobri, for five years, until 1897. Dr. Zaharija Popović became physicus in 1898 and 1899, and was succeeded by Dr. Selimir Djordjević, who worked until 1908. He was the last physicus of the $19^{\text {th }}$ and the first one of the $20^{\text {th }}$ century [10].

Since 1908, there had been one physicus for the entire Moravian District, based in Cuprija. From 1908 until the World War I, seven hospital directors, or district physi- cuses, worked in Ćuprija: Dr. Mihajlo Cvijetić (1899-1900), Dr. Josif Vidaković (1900-1902), Dr. Radivoje Vukadinović (1902-1904), Dr. Mita Nikolić (1904-1906), Dr. Djordje Petrović (1906-1907), Dr. Djoka Jovanović (1907-1914), and Dr. Nikolai Semashko (1914-1915), while Dr. Radivoje Vukadinović (1893-1902), Dr. Vojislav Vukomanović (1909-1910), Dr. Ilija Mirčić (1910-1912), and Dr. Franja Danilović (1912-1914) worked as secondary doctors of the hospital [18].

\section{CONCLUSION}

Dynamic changes that took place in Serbia and among Serbian people in the $19^{\text {th }}$ century (population composition and growth, industrial development, institutionsbuildings and civilizational progress) were visible even in Jagodina, which was changing equally and simultaneously with the entire society. Fourteen district physicuses of the $19^{\text {th }}$ century, from 1839 and Dr. Karlo Beloni, to the last one, Dr. Selimir Djordjević, spent part of their professional careers in Jagodina. All of them left their humane and human mark on raising health culture of Jagodina and its population and helped overcoming more easily and quickly all existing diseases and epidemics. The Jagodina Hospital has been working without interruption for 147 years and represents one of the oldest healthcare institutions in Serbia.

\section{ACKNOWLEDGMENTS}

This study was supported by the by the Ministry of Education, Science and Technological Development of the Republic of Serbia, project No 172026.

\section{REFERENCES}

1. Mitić B. Zdravstvene prilike u Srednjem Pomoravlju, Resavi i Levču od 1804. do 1915. godine. Ćuprija: Opština Ćuprija; 2006.

2. Marković R. Vojska i naoružanje Srbije Kneza Miloša. Beograd: Srpska akademija nauka; 1957. 
3. Dedić D. Kuga u Jagodini 1837. godine. Internet izdanje. Jagodina: Istorijski arhiv Jagodina; 2009. Available from: http://www.arhivja.org rs/images/kuga_u_jagodini_1837.pdf.

4. Gavrilović V, Zagrađanin D. Istorija stomatološke sekcije SLD. Beograd: Srpsko lekarsko društvo; 1984.

5. Nedok A. Osnivanje i počeci rada prve vojne bolnice u Beogradu. Vojnosanit Pregl. 2009; 66(3):245-8. [PMID: 19341234]

6. Jovanović D, Tanić D. Od Josifa Pančića do Spiridona Jeftimijadesa: prilozi za istoriju zdravstva u Jagodinskom okrugu 1847-1860. Internet izdanje. Jagodina: Istorijski arhiv Jagodina; 2009. Available from: http://www.arhivja.org.rs/images/od_josifa_pancica.pdf.

7. Maksimović J. Doprinos lekara iz Vojvodine u uspostavljanju zdravstvene službe u Srbiij u osnivanju i radu Srpskog lekarskog društva. Med Pregl. 2008; 61(3-4):191-203. [DOI: 10.2298/MPNS0804191M] [PMID: 18773699]

8. Vetnić S. Pioniri zdravstva u Jagodini. Svetozarevo: GIP Novi put; 1992.

9. Pirh Oto D. Putovanja po Srbiji u godini 1829. Beograd: Prosveta; 1983.

10. Marjanović V. Zdravstvena kultura Jagodine u XIX veku. Svetozarevo: Medicinski centar; 1972.

11. Dimitrijević B. Operisali i nesvršeni studenti medicine. Glasnik Lekarske komore Srbije. 2012; 4(13):74-5.

12. Jovanović D, Tanić D, Dedić D. Rad dr Karla Belonija, prvog fizikusa Okruga jagodinskog. Jagodina: Istorijski arhiv Jagodina; 1995.
13. Stanojević V. Likovi i dela istaknutih srpskih lekara pre osnivanja Srpskog lekarskog društva. In: Djurić DS, editor. Spomenica Srpskog lekarskog društva 1872-1972. Beograd: Srpsko lekarsko društvo; 1972. p.22-55.

14. Cvetić E. Iz istorije stare Jagodine: geografsko-istorijska rasprava. Svetozarevo: SIZ za kulturu, Pedagoška akademija; 1988.

15. Ravanić BD, Pantović MM, Milovanović SD. Dr Mladen Janković ličnost i delo (1831-1885). Srp Arh Celok Lek. 2007; 135(7-8):495-9. [PMID: 17929546]

16. Despotović M. Vremeplov zdravstva u Jagodini. Bolnica Jagodina Info. 2014; (8):2. Available from: http://issuu.com/brakusslavoljub/ docs/info 8 .

17. Arhiv Srbije, Beograd, Ministarstvo Unutrašnjih Dela, Sanitetski Fond i popisnik 35/872; Sanitetski Fond i popisnik 36/874; Gradjanska Kartoteka, Fascikla 12 i popisnik 33/897, Fascikla 12 i popisnik 2/897, Fascikla 12 i popisnik 34/897; Delovodni Protokol 3062/892; Gradjanska Kartoteka, Fascikla 9 i popisnik 21/888, Fascikla 2 i popisnik 34/897; Delovodni Protokol. Ch 1514/896; Ministarstvo Unutrašnjih Dela, Sr. 92/898, 634/905, 46/907 i 535/909

18. Mitić B. Zdravstveni centar u Ćupriji - od prvih lekara do današnjih dana. Ćuprija: Zdravstveni centar u Ćupriji, Podružnica Srpskog lekarskog društva Pomoravlje Ćuprija; 2005.

Received: 26/03/2015 • Accepted: 15/09/2015 


\title{
Istorija medicine u Jagodinskom okrugu
}

\author{
Marko Jeremić, Ana Vuković2 , Ninoslav Stanojlović3, Rade Vuković ${ }^{4}$, Dejan Marković \\ 'Stomatološka služba, Dom zdravlja, Jagodina, Srbija; \\ 'Univerzitet u Beogradu, Stomatološki fakultet, Klinika za preventivnu i dečju stomatologiju, Beograd, Srbija; \\ ${ }^{3}$ Osnovna škola „17. oktobar", Jagodina, Srbija; \\ "Institut za zdravstvenu zaštitu majke i deteta Srbije „Dr Vukan Čupić“, Beograd, Srbija
}

\begin{abstract}
KRATAK SADRŽAJ
Prvi zapis o postojanju naučne medicine u Srbiji potiče iz ranog 12. veka. Stolećima je zdravstveno stanje srpskoga naroda bilo pod uticajem faktora kao što su način života, ishrana, prirodno okruženje, vojske koje prolaze, kulturno nasleđe i predrasude. Do 1820. godine u Srbiji nije bilo obrazovanih lekara. Četrnaest okružnih fizikusa od 1839. godine i dr Karla Belonija, do poslednjeg, dr Selimira Đorđevića, proveo je deo svoje profesionalne karijere u Jagodini. Svi oni su ostavili svoj humani i profesionalni trag na podizanju zdravstvene kulture Jagodine i njenog stanovništva, te pomogli lakše i brže prevazilaženje svih postojećih bolesti i epidemija. Bolnica u Jagodini radi bez prekida 147 godina i jedna je od najstarijih zdravstvenih ustanova u Srbiji.
\end{abstract}

Ključne reči: dom zdravlja; javna zdravstvena služba; istorija medicine; društveni razvoj

Pravi ljudi od nauke duboko poštuju prošlost. Sve što radimo i sve što jesmo rezultat je stogodišnjeg rada. Ernest Renan (1823-1892)

\section{UVOD}

Još od praistorije i nastanka čoveka istorija medicine proučava postanak i razvitak bolesti, kao i njihovo lečenje. Smatra se da su bolesti nastale kada i čovek, i da otada i počinje potreba za njihovim lečenjem. Poreklo i nastanak medicine su posledica ljudskih nagona za zaštitu i odbranu. Uporedo s empirijskom (iskustvenom) medicinom razvila se anemistička ili magijska medicina, koja je imala duhovni karakter i nastala na verovanjima u svet duhova prirode, biljaka, životinja i predmeta. Verska medicina je bila najčešća u Starom i Srednjem veku, a bolesti su tumačene kao posledica delovanja zlih duhova, koji su narušavali postojeću ravnotežu u organizmu čoveka. Apokrifna medicina, koju su Sloveni zatekli kod starosedelačkog stanovništva Balkana, nastala je kao rezultat ukrštanja različitih orijentalnih i antičkih kultova, kao i filozofskih sistema Starog veka. Zvanična crkva je nije priznavala zbog njene prirode i verovanja u negativno dejstvo zlih sila iz prirode. Lečenje se vršilo molitvama i gatanjem [1].

Ova studija je opisno istraživanje razvoja medicine u Srbiji i Jagodinskom okrugu. Pratili smo razvoj medicine od srednjovekovnog perioda do danas. Kao metode korišćeni su analiza dokumentacije i prikupljanje i analiza sekundarnih podataka. Istorijski podaci su prikupljeni kroz intervjue i analizirani.

\section{RAZVOJ MEDICINE U SREDNJEM VEKU}

Prvi pomen o postojanju naučne medicine u Srbiji postoji još od početka 12. veka i predstavljala je, kao i evropska, medicinu Hipokrata, Galena, Aristida i drugih antičkih lekara. Bila je u velikom usponu od 12. do 15. veka. Prenosioci medicinskih znanja iz Vizantije u Srbiju mahom su bili kaluđeri u srpskim ili vizantijskim kolonijama na Atosu, Sinaju i u Jerusalimu, dok su zapadnu medicinu prenosili lekari i apotekari školovani u zapadnim medicinskim školama. Osnivači prvih bolnica su bili Stefan Nemanja i Sveti Sava 1191. godine u manastiru Hilandaru, a prvu bolnicu na teritoriji Srbije osnovao je Sveti Sava 1208. godine u
Studenici. Kasnije ih je osnovano još nekoliko (Ravanica, Visoki Dečani) i one su radile do propasti srpskih srednjovekovnih država [2]. Naučna medicina srednjovekovne Srbije je prekinuta u daljem razvoju, sve više je stagnirala, da bi na kraju 17. veka bila svedena samo na narodnu i donekle versku medicinu.

Zdravstvene prilike u srpskom narodu bile su uslovljene različitim faktorima kao što su način života, ishrana, prirodna sredina, prolazak vojski, nasleđe i predrasude. Lečenje je bilo primitivno i narod se po većim mestima lečio kod narodnih lekara: berbera - Turaka, koji su puštali krv rogovima i pijavicama, vadili zube i vršili manje operacije; hećima - Grka poreklom iz Epira, koji su bili nastanjeni u pojedinim mestima, nazivani su i, „kalojatri“ (gr. dobri lekari), koji su znanje porodično nasleđivali; samoukih lekara (po narodnosti Grci, Srbi ili Turci) i narodnih vidara i vidarica (Grci, Jevreji i Romi), koji su veštinu lečenja prenosili s kolena na koleno [3].

Narod van većih mesta, po selima, lečio se u manastirima, kod kaluđera koji su znali tajne lečenja lekovitim biljem iz knjiga „lekaruša“, koje su vremenom menjane i dopunjavane, i kod popova, koji su obolele lečili čitanjem molitvi i „utiskivanjem krsta“ na obolelo mesto. Narodni lekari, kojih je bilo u skoro svakom selu, lečili su biljkama, melemima, lekovitim travama i bajanjem. To su uglavnom bile starije žene koje su prestale $s$ rađanjem i bile upućene u njihovu pripremu. Znanje su prenosile na mlađu žensku osobu iz porodice (uzrasta do 12 godina).

Nadrilekarstvo nije postojalo u klasičnom smislu, jer školovanih lekara nije ni bilo. U radnjama po većim mestima mogli su da se kupe svi poznati lekovi, od kojih su neki bili i otrovni i prodavani bez kontrole. Tridesetih godina 19. veka se sprovode i mere za suzbijanje nadrilekarstva, ali narod nije dugo mogao da se oslobodi sujeverja i ukorenjenih shvatanja.

\section{RAZVOJ MEDICINE U DOBA USTANAKA}

Srbija je pod viševekovnom turskom upravom bila zaostala u svakom kulturnom napretku i bez lekara, ne samo u vreme ustanaka, već i mnogo godina kasnije. Neprosvećenost naroda, turska plačkanja i gubici u ustancima nisu pružali kulturne i materijalne uslove za dolazak i rad stranih lekara. Prvi lekari, koji su dolazili retko i samostalno, bili su lični lekari beogradskog paše, a potom u službi Kneza i njegovog dvora. Kasnije su 
ti lekari primani u vojnu službu kao vojni lekari u vojsci koja se tek počela stvarati [1].

Tokom Prvog i Drugog srpskog ustanka ranjenici su lečeni po manastirima i kod svojih kuća. Pri kraju Karađorđeve vlade u Srbiji su postojale i dve bolnice - jedna u Beogradu, druga u Šapcu. Lekarski stalež je bio ograničen na lekare strance i retke lekare Vojvođane primljene u vojnu i građansku službu. To je vreme kada Srbija, u koju se vraćaju mladi intelektualci sa studija iz inostranstva, pokušava da promeni konzervativni i patrijarhalni način života [4].

Srbija je u prvim decenijama 19. veka bila još nedovoljno formiran deo Turskog carstva, bez domaćih školovanih kadrova, siromašna i u svakom pogledu nerazvijena [5].

\section{RAZVOJ MEDICINE U OSLOBOĐENOJ SRBIJI}

Do 1820. godine u Srbiji nije bilo školovanih lekara. Prvi diplomirani lekar u Srbiji bio je Konstantin Aleksandridi, drugi je Italijan Vita Romito, na čiji poziv je 1826. godine kao treći došao njegov zemljak dr Bartolomeo Silvester Kunibert, koji će do 1839. raditi kao lični lekar kneza Miloša [6].

Prvi Srbin lekar u Miloševoj Srbiji bio je dr Jovan Stejić. Rođen je 1803. godine u Aradu. Doktorirao je u Beču 1829. godine zahvaljujući pomoći Jevrema Obrenovića. Kao lekar prešao je u Srbiju kod Jevrema, ali ga je ubrzo preuzeo knez Miloš za svog ličnog lekara i vaspitača svojih sinova Milana i Mihaila. Zbog neslaganja s Milošem, on prelazi u Zemun, koji je tad bio van granica Srbije. Po Miloševom odlasku iz Srbije 1840. godine vratio se u Beograd i zajedno sa dr Karlom Pacekom osnovao Srpski građanski sanitet. Godine 1845. postavljen je za sekretara Državnog sovjeta, najvišeg upravnopolitičkog tela, i na tom mestu ostao do svoje smrti 1853. godine [7].

Osim njih, kao lekari u Srbiji su do 1839. godine kao stranci radili $\mathrm{i}$ :

- dr Nestor Mesarović, iz Iriga, knjažev lekar u Kragujevcu;

- dr Karlo Pacek, iz Budimpešte, veliki prijatelj i savetnik Dinastije Obrenovića, imao je veliki značaj u formiranju zdravstvene službe u Srbiji;

- dr Đorđe Pantelić, lekar kneževe porodice u Požarevcu i kasnije vojni lekar garde;

- dr Maksim Nikolić Miškovičev, iz Sremskih Karlovaca, službovao kao vojni lekar;

- dr Emerih Lindenmajer, iz Banata, prvi šef Vojnog saniteta, načelnik vojne i građanske zdravstvene službe;

- dr Josip Rabrić, iz Sremskih Karlovaca, karantinski lekar u Aleksincu i Kragujevcu;

- dr Herman Majnert, iz Češke, došao u Srbiju 1836. godine [1].

\section{RAZVOJ MEDICINE U JAGODINI PO OSLOBOĐENJU OD TURAKA}

Prvi priučeni lekar došao je u Jagodinu po okončanju Drugog srpskog ustanka. Prema pismu Janićija Radovića, starešine Jagodinske mezulhane (pošte, gostionice za kurire, gde su oni menjali konje i nastavljali put ka Carigradu ili Pešti), upućenom Knezu Milošu 1824. godine, bio je izvesni Gvido, Italijan, na putu za Carigrad. Sa sobom je vodio i apotekara Tristana i pratioca Petra, a osim italijanskog, znao je i turski jezik, te su uz njegovu pomoć putovali kroz balkanske krajeve [8].

Istoričar i putopisac Oto Dubislav Pirh 1829. godine pominje u svojim „Putovanjima po Srbiji u godini 1829.“ samo šest lekara, od kojih jedan, Đorđe Novaković, ili Leonid Erlih, živi u Jagodini. On je bio pokršteni Jevrejin rođen u Poljskoj, lekar austrijske vojske, iz koje je prešao u Šabac. Jedan je od prvih hirurga u Srbiji, a u Jagodini je radio od 1826. godine [9]. U 18. i 19. veku veliki deo Evrope često su zahvatale epidemije raznih bolesti. U Srbiju su se širile preko Turske. Česte zaraze i opasnost prodiranja epidemija preko granica dovele su da se tridesetih godina 19. veka krene sa podizanjem karantina na glavnim graničnim prelazima i da se istovremeno osnuju pogranični sanitetsko-policijski kordoni. Najopasnije su bile epidemije kolere i kuge koje su u nekoliko navrata pogađale stanovništvo tadašnje Srbije [3]. Prilikom poslednjeg širenja kuge na teritoriju Srbije i Evrope iz Turske, 1837. godine glavna borba je vođena u Jagodini, jer je ona bila i centar zaraze. Bio je pozvan dr Karlo Nađ iz Zemunskog karantina kao glavni ekspert, a kao savetnici sarađivali su dr Pacek, dr Lindenmajer i dr Kunibert. Knez Miloš mu je dao svu moć i vlast i uputio ga u Jagodinu. Epidemija je zaustavljena za tri i po meseca.

Dana 17. aprila 1839. godine Ministarstvo unutrašnjih dela sa Sanitetskim odeljenjem, pod čiju nadležnost je spadala sanitetska struka u osnivanju - lekari, okružni fizikusi, apoteke i apotekari, bolnice i babice, predlagalo je da se za svaki okrug u Srbiji postavi po jedan lekar, i to: sa doktorima medicine Šabac, Beograd, Smederevo, Jagodina, Čačak i Užice; sa hirurzima Valjevo, Beograd, Milanovac, Zaječar, Soko Banja, Kruševac i Kraljevo; sa postojećim vojnim lekarima Kragujevac i Požarevac. Dana 24. jula 1839. godine, naredbom Đorđa Protića, ministra unutrašnjih dela, i dr Karla Paceka, privremenog načelnika Saniteta Kneževine Srbije, ustanovljeni su zdravstveni punktovi u zemlji i postavljeni: okružni fizikusi u Šapcu, Beogradu, Smederevu, Jagodini, Čačku i Užicu, a hirurzi u Valjevu, Beogradu, Milanovcu, Zaječaru, Banji, Knjaževcu i Kraljevu, dok su vojni lekari pridodati Kragujevcu i Požarevcu, jer su se u njima nalazile jedinice kneževe garde.

Prema uputstvu dr Paceka, zadatak okružnih fizikusa je bio da vakcinišu stanovništvo, zabranjuju upotrebu nezdravih jela i pića, sprečavaju nadrilekarstvo, nadziru trgovanje lekovima, poučavaju narod o higijenskim navikama, obavljaju sudsko-lekarske dužnosti (vrše vizitiranje i daju mišljenje o sposobnosti lica za službu, ženidbu i brak, ili o ubijenim, otrovanim i tučenim), vrše obdukcije i obavljaju potrebne veterinarske poslove na sprečavanju širenja bolesti među životinjama. U čisto lekarske poslove ubrajali su se: poseta bolesnicima, davanje mišljenja o sposobnosti pojedinca za određeno zanimanje, naročito državnu službu, i sposobnosti za ženidbu, veštačenje u slučajevima ubistva, trovanja i tuča, lečenje pojedinačno i u bolnicama, izdavanje lekova iz ručne apoteke u mestima gde nema javnih apoteka i podnošenje izveštaja o radu. Istovremeno je trebalo, u nedostatku sreskih i varoških lekara, da leče obolele u kućama i „špitaljima“ (bolnicama), kao i da nose lekove u ručnim apotekama ukoliko u njihovom mestu još nije bila otvorena apoteka.

Pre nego što su postavljeni fizikusi po okruzima, doneta su važna pravna akta u zdravstvenoj kulturi. Prvi je bio iz 8. jula 1839. godine o obavezi vakcinisanja stanovništva protiv velikih boginja, sa detaljnim opisom svih postupaka lekara [10].

Lindenmajerov spisak lekara i medicinskog kadra iz 1839. godine glasio je ovako: 
1. Dr Pacek - dvorski i lični lekar kneza Miloša;

2. Dr Nikolić Mišković - dvorski lekar kneževe porodice;

3. Dr Emerih Lindenmajer - gardijski lekar u Kragujevcu;

4. Dr Karlo Beloni - lekar komande u Čačku;

5. Dr Rebrić - privatni lekar u Beogradu;

6. Dr Majnert - gardijski lekar u Beogradu;

7. Dr Mušicki - karantinski lekar u Aleksincu;

8. Dr Mihajlović - karantinski lekar u Svilajncu;

9. Dr Slavuj, magistar hirurgije - drugi gardijski lekar u Beogradu;

10. Dr Đorđe Novaković - hirurg;

11. Dimitrije Kaparis - bez zvanične diplome pri gardi u Požarevcu;

12. Sava Jovanović - pri karantinu;

13. Privatni apotekar Mata Ivanović u Beogradu;

14. Pavle Ilić - dvorski apotekar i apotekar vojne garde u Kragujevcu;

15. Dr Šteker - lekar turskog garnizona u Beogradskoj tvrđavi;

16. Dr Florijan Birg, magistar hirurgije - drugi lekar turskog garnizona i apotekar turske bolničke ustanove [11].

Smatra se da su pravila o radu budućih fizikusa napisali dr Karlo Pacek i dr Jovan Stejić po ugledu na Austrougarski pravilnik o kalemljenju kravljih boginja. Godine 1842. Zakon o obaveznom vakcinisanju je proširen i dopunjen i bio je još stroži. Zahtevao je pisanu potvrdu o vakcinisanju za stupanje u brak, dobijanje stipendije za nastavak školovanja, za obavljanje državnih poslova u policiji, prosveti i sveštenstvu. Dana 21. avgusta 1839. godine doneta su Pravila u radu za buduće fizikuse, ili Nastavlenia za okružne lekare i fizikuse. Pravilnik je imao 23 tačke i predstavljao je prvi sanitetski zakon [10].

\section{RAZVOJ ORGANIZOVANOG SISTEMA ZDRAVSTVENE ZAŠTITE U JAGODINI U 19. VEKU}

Za drugog okružnog fizikusa Jagodinskog okruga postavljen je dr Karlo Beloni (Slika 1), koji je dotad bio lekar Garde i Moravsko-podrinjske komande u Čačku, sa stažom od četiri i po godine i godišnjom platom od 300 talira [12]. Jagodinski okrug, u koji je upućen dr Beloni kao jedini lekar, imao je 1839. godine 6.674 domaćinstva: Temnićki srez 3.471, Levački srez 3.155, a Jagodina i okolina 546 domaćinstava. Tokom boravka u Jagodinskom okrugu dr Beloni je pretpostavljenim starešinama dostavljao mesečne izveštaje o radu. Dr Beloni je rođen 1812. godine u mestu Levici, u mađarskoj oblasti Barš Marmeđa. Poticao je iz rimokatoličke porodice. Na univerzitetu u Pešti je stekao diplomu sa zvanjima doktora medicine i magistra okulistike i opstetricije (akušerstva). Do prelaska u Srbiju nije nigde službovao na teritoriji mađarske države, već je tokom četiri godine i sedam meseci jedino radio u Srbiji, od čega tri godine i pet meseci kao vojni lekar u Čačku, Karanovcu, Beogradu, Kragujevcu i Ćupriji. Bio je dobrog telesnog stasa i zdravlja. Znao je prilično dobro da govori i piše na srpskom jeziku. U izveštajima dr Beloni piše da je tokom poseta zaticao dobro opšte zdravlje naroda i stoke, da nije bilo težih epidemija i da su mu se bolesnici obraćali za pomoć u „umerenim razmerama“. Oboleli su se mahom žalili na kataralna i reumatična zapaljenja i na oboljenja od groznice, zapaljenja „džigerice“ i reumatizam. Nije bilo ni „rednji“ kod stoke, sem besnila pasa, što je, prema njegovoj oceni, bila posle- dica jake zime. Okružni načelnik je, međutim, isticao da se dr Beloni sreo na terenu sa nizom poteškoća, koje su proizilazile iz zdravstvene neprosvećenosti naroda, te su oboleli bežali od njegovih usluga čak i po cenu kažnjavanja od vlasti. Inače, težio je da bude tačan u obavljanju policijsko-lekarskih dužnosti, naročito kod vizitacije umrlih, i trudoljubiv kod kalemljenja boginja, ali su roditelji nerado dovodili decu na pelcovanje.

Kod izdavanja uverenja je postupao predostrožno, nepristrasno i istinito. Sa sobom je nosio poveliku apoteku, snabdevenu u svako doba potrebnim medikamentima. Lekove je poklanjao siromašnima, a imućnima naplaćivao. Imao je uspeha u lečenju, posebno težih bolesnika od srdobolje i vrućice, ali opšte poverenje naroda prema njegovom radu, zbog straha i sujeverja, nije bilo dobro. Inače je bio krotke naravi, pa je u ophođenju sa zdravima bio dobar, a sa bolesnicima strpljiv. U proleće 1841. godine dr Beloni je još jednom preuzeo širu vizitaciju okruga, ali je i ona prošla bez vidnijih rezultata. U levačko selo Kavadar, u kojem je vladala epidemija boginja, išao je uzaludno tri puta, čak u pratnji sreskog načelnika i policije, ali nijednom nije zatekao obolelu decu u kućama, jer su ih roditelji krili u šumi. Razočaran ovakvim držanjem naroda i ličnim neuspehom, dr Beloni se odlučio da zatraži premeštaj u neko drugo mesto, gde bi njegov rad dao vrednije rezultate. U maju 1841. godine dr Beloni ja zatražio od nadležnih vlasti premeštaj u Čačanski okrug, navodeći svoje uverenje da će tamo biti korisniji, jer je za vreme ranijeg službovanja u tom kraju zadobio veće poverenje naroda i imao mnogo više uspeha u radu [10]. Do postavljenja novog fizikusa $\mathrm{u}$ Jagodini povremena lečenja preduzimali su fizikusi iz okolnih područja. Dr Dimitrije Kaparis, fizikus Požarevačkog okružja, radio je od decembra 1841. godine na suzbijanju epidemije velikih boginja u nekim selima Jagodinskog okruga. Dužnost okružnog fizikusa do početka 1844. godine, bez formalnog postavljenja, ali uz dopuštenje dr Jovana Stejića, načelnika Saniteta, koji je na toj funkciji zamenio dr Karla Paceka, obavljao je Gligorije Ribakov.

Ukazom kneza Aleksandra Karađorđevića, 10. januara 1844. godine za drugog po redu okružnog fizikusa postavljen je dr Andrej Ivanović. Bio je fizikus do 1847. godine, kada podnosi ostavku i prelazi na mesto fizikusa Negotinskog okruga. Bio je fizikus u Jagodini tri godine i 15 dana. Dr Ivanović je pored svojih redovnih obaveza tražio i da se snabdevanje vodom za piće reguliše kopanjem novih bunara, da se đubre ukloni iz dvorišta, dvorišta čiste, vrši higijena, da se ulice u gradu popune kamenom (kaldrmišu). Obavljao je i veterinarske poslove. Osnovao je i prvu bolnicu u Jagodini, koja je bila na nivou privatne ordinacije [13].

Treći fizikus po redu je bio dr Josif Pančić (Slika 2), koji u Jagodinu dolazi 31. januara 1847. godine na poziv Avrama Petronijevića, vlasnika Staklare, zbog pojave epidemije trbušnog tifusa kod radnika fabrike. On je uspeo da zaustavi epidemiju i kod radnika Staklare i kod stanovnika okolnih sela. Zbog uspeha u lečenju, stanovništvo Jagodine je tražilo da se Josif Pančić postavi za okružnog fizikusa. Dosta je radio na zdravstvenom obrazovanju naroda. To je naročito činio pisanim uputstvima o sprečavanju i lečenju pojedinih bolesti, kao i usmenim savetima. Ukazivao je na ishranu kao uzročnika mnogih bolesti [13].

Istovremeno s postavljanjem Josifa Pančića za fizikusa Kragujevačkog okruga, za četvrtog fizikusa Jagodinskog okruga 20. novembra 1847. godine postavljen je dr Đorđe Malać, rodom iz Osijeka u Slavoniji, koji je medicinu završio u Budimpešti. Pored samog lečenja veliki deo svoje aktivnosti fizikusi su posvetili 
upornim nastojanjima u borbi protiv zaostalosti, ali bez mnogo uspeha. U svojim izveštajima dr Malać navodi da u Jagodini postoje okružno načelstvo, okružni sud, osnovna škola i improvizovana bolnica. Takođe navodi veliku neuređenost ulica, dvorišta, nedostatak pijaće vode, opisuje stoku koja se slobodno kretala. Navodi da je tokom 1848. godine lečio ukupno 280 lica i da su se određene bolesti pojavljivale s godišnjim dobima. Najviše bolesnika je bilo među radnicima fabrike stakla u Belici, a opisuje i da su se u Jagodini, a najviše po selima, ljudi češće okretali vradžbinama i narodnim lekovima. Zabrana prodaje otrovnih materija u trgovačkim radnjama nije se potpuno poštovala, što nije bio slučaj samo u Jagodini, već i čitavoj Kneževini.

Posle ostavke dr Đorđa Malaća, za novog fizikusa Okruga postavljen je Bogomir (Godfrid Anton) Šulek, iz Češke, koji je medicinu završio u Beču. On je boravio u Jagodinskom okrugu od marta 1851. do juna 1852. godine. Sledeći je bio dr Jovan Valenta, Čeh, koji je medicinu završio u Pragu i koji je službovao $\mathrm{u}$ avgustu i septembru 1852, a potom je za fizikusa određen $\mathrm{dr}$ Spiridon Jeftimijades, rodom iz Turske, koji se na toj poziciji zadržao do 1860. godine [13].

Prema raspisu Ministarstva unutrašnjih dela od 8. marta 1852. godine, okružni načelnici su dobili zaduženja da - uz pomoć okružnih fizikusa i opštinskih odbora - nađu podesnu zgradu sa najmanje dve odaje i kuhinjom, opreme je nužnim inventarom i otvore bolnicu. Osnivanjem bolnice u Jagodini rukovodio je predsednik Prvostepenog suda Stevan Stevanović, sa pisarem Aleksandrom Jakovljevićem i uz neslužbenu pomoć grupe dobrotvora. Prilozima varoških esnafa je prikupljen 3.761 groš, te je uzeta pod zakup omanja zgrada i opremljeno šest kreveta. Bolnica je otvorena krajem leta 1852. U martu 1858. godine u štampi je objavljena vest da je kupljena nova zgrada za bolnicu i da se u njoj okupilo nekoliko bolesnika, ali je i dalje radila bez stručne nege i pouzdanih prihoda. Početkom 1860. okružni fizikus dr Spiridon Jeftimijades navodi u izveštaju da u varoši „špitalja gotovo nema, samo što opština privatno drži jednu kućicu na kraj varoši blizu groblja, u kojoj se neki sakati nalaze“, a u oktobru iste godine novopostavljeni fizikus dr Mladen Janković piše vlastima da „opštinsku bolnicu“ nije niko posetio tokom celog meseca. Prema navodima iz njegovog izveštaja s početka naredne godine, bolnica je bila u lošem stanju, bez opreme i stručne nege, pa je više ličila na ubožište za bogalje i nemoćne pojedince bez staratelja, nego na zdravstvenu ustanovu [14]. Na dužnosti fizikusa je ostao oko godinu i po dana. Godine 1884. bio je postavljen za vršioca dužnosti načelnika saniteta u Ministarstvu unutrašnjih dela. Bio je jedan od osnivača Srpskog lekarskog društva i osam godina njegov predsednik (od 1873) [15].

Dr Mladena Jankovića je na mestu fizikusa 1862. godine zamenio dr Milosav Pavlović, prvi školovani lekar iz Pomoravskog kraja, i ostao fizikus narednih 11 godina. Dr Pavlović se rodio 1827. godine u selu Dražimirovcu kod Jagodine. Gimnaziju je počeo da pohađa 1845/46. godine u Beogradu, a medicinu diplomirao u Carigradu. U Parizu je proveo godinu na dopunskim studijama. Znao je turski, grčki, ruski i francuski jezik. Tokom 1860. godine postavljen je za lekara u Raškoj, a 20. oktobra 1861, $\mathrm{u}$ to vreme sa statusom ,izvanrednog fizikusa na raspolaganju“, za okružnog fizikusa u Jagodini [16].

Godine 1865. donet je Zakon o podizanju i ustrojstvu bolnica. Ministarstvo unutrašnjih dela je 16. novembra 1866. uputilo zahtev načelstvima u Podrinjskom, Užičkom, Aleksinačkom, Cr- norečkom, Smederevskom, Valjevskom, Jagodinskom, Rudničkom i Ćuprijskom okrugu, da nađu za privremene bolnice neku privatnu kuću ili opštinsku za izdavanje za opštinsku bolnicu. Bolnica je otvorena u kući Avrama Petronijevića, ministra inostranih dela, čija je porodica živela u Jagodini, vlasnika fabrike stakla u Belici, građenoj 1833. godine, koja je uzeta u zakup od njegovog naslednika iz Beograda.

Okružna bolnica u Jagodini je osnovana 1. novembra 1867. godine (Slika 3), a njen osnivač je bio okružni fizikus dr Milosav Pavlović. U bolnici se u proseku lečilo leti 10-15, a zimi 30-35 bolesnika. Bolnica je po otvaranju nazvana Okružni špitalj. Upravnici bolnice od njenog osnivanja do kraja 19. veka bili su, posle dr Milosava Pavlovića, dr Leopold Levi, opštinski lekar (1873-1874), dr Kazimir Staniševski, okružni fizikus (1875-1883), dr Franja Ribnikar, opštinski lekar (1883-1888), dr Stevan Siber, okružni fizikus (1889-1891), dr Jovan Danić, okružni fizikus (1891-1892), dr Venceslav Steiskal, sreski lekar (1892-1893), dr Pera Dobri, okružni fizikus (1893-1898), dr Zarije Popović, okružni fizikus (1898-1900), dr Selimir Đorđević, okružni fizikus (1900-1908) i dr Živojin Milenković, sreski lekar (1908-1914) [17]. Od 1891. godine, nakon spajanja Jagodinskog i Ćuprijskog okruga u Moravski, sa sedištem u Ćupriji, i dalje je zadržala okružni status za Belički, Temnićki i Levački srez. Tek 1907. godine dobila je sreski, ali je 1909. ponovo vratila okružni značaj.

Po zakonu o uređenju sanitetske struke i očuvanju narodnog zdravlja iz 1881. godine, svaka oblast, srez, treba da ima svog sreskog lekara, koji treba da ima istu kvalifikaciju kao i fizikus. Njega postavlja Knez ukazom na predlog ministra unutrašnjih poslova - ako je srpski državljanin, za dejstvateljnog, a ako je strani, za kontraktualnog. Jagodinski okrug je u to vreme imao tri sreza - Belički, Levački i Temnićki. Lekari Beličkog sreza su bili dr Josif Vidaković (1890), dr Veneslav Steiskal (1891-1892), dr Dragoljub Đorđević (1895-1898), dr Živojin Milenković (1901-1902), dr Kosta Ristić (1903-1904), dr Đorđe Hadi (1905) i ponovo dr Živojin Milenković (1906-1914). Lekari Levačkog sreza bili su: dr Ilija Jovanović (1896), dr Dragoljub Đorđević (1897), dr Ilija Ivanović (1898-1903), dr Vladimir Popović (1907), dr Svetislav Šohajević (1908-1910) i drugi [1].

Prema ovom zakonu, svaka opština u Srbiji sa 10.000 stanovnika bila je dužna da izdržava opštinskim porezom po jednog opštinskog lekara, koji je bio i član opštinske uprave. Sva pitanja koja su se odnosila na zdravlje ljudi i veterinarska pitanja nisu se mogla rešiti bez njegovog prisustva. U slučaju rata, obavljali su svoje lekarske dužnosti u vojnim bolnicama.

Opštinski lekari u Jagodini bili su: dr Gligorije Ribakov (1835), dr Leopold Levi (1875-1879), dr Franja Ribnikar (1883-1889), dr Gorgije Zinovjev (1889-1890), dr Radivoje Vukadinović (1891-1898), dr Venceslav Steiskal stariji (1899-1900), dr Vojislav Stefanović (1904), dr Svetislav Stefanović (1905) i dr Damnjan Tufegdžić (1910-1914) [1]. Godine 1873.i 1874. nije bilo fizikusa. Na početku srpsko-turskih ratova (1876-1878) Jagodina je imala okružnu bolnicu i gradsku apoteku. Dr Kazimir Staniševski je bio okružni fizikus i upravnik Okružne bolnice, a dr Franja Ribnikar je vršio dužnost opštinskog lekara. Godine 1891. za fizikusa je postavljen dr Stevan Siber i na toj dužnosti ostao godinu dana. Jedanaesti fizikus je bio dr Jovan Danić, 1892.i 1893. godine. Dvanaesti je bio dr Pera Dobri, koji je vršio dužnost fizikusa pet godina, do 1897. Dr Zarija Popović je bio na tom mestu 1898. i 1899. godine, a posle njega dr Selimir Đorđević, do 1908. godine. On je bio i poslednji fizikus u 19. i prvi u 20. veku [10]. 
Od 1908. godine postojao je za ceo Moravski okrug jedan fizikus sa sedištem u Ćupriji. U Ćupriji je od 1908. godine do Prvog svetskog rata radilo sedam upravnika bolnice, ili okružnih fizikusa, i to: dr Mihajlo Cvijetić (1899-1900) , dr Josif Vidaković (1900-1902), dr Radivoje Vukadinović (1902-1904), dr Mita Nikolić (1904-1906), dr Đorđe Petrović (1906-1907), dr Đoka Jovanović (1907-1914) i dr Nikolaj Semeško (1914-1915). Kao sekundarni lekari Bolnice radili su: dr Radivoje Vukadinović (1893-1902), dr Vojislav Vukomanović (1909-1910), dr Ilija Mirčić (1910-1912) i dr Franja Danilović (1912-1914) [18].

\section{ZAKLJUČAK}

Dinamične promene koje su se događale u Srbiji i srpskom narodu u 19. veku bile su vidljive i u Jagodini, koja se menjala kao i čitavo društvo oko nje, u pogledu sastava stanovništva, njegovog broja, stepena industrijskog razvoja, izgradnje ustanova i civilizacijskog napretka. Četrnaest okružnih fizikusa u 19. veku, od 1839. i dr Karla Belonija, do poslednjeg, dr Selimira Đorđevića, deo je svoje profesionalne karijere proveo u Jagodini. Svi oni su ostavili svoj humani i profesionalni trag na podizanju zdravstvene kulture Jagodine i njenog stanovništva i pomogli da se sve bolesti i epidemije koje su postojale lakše i brže prevaziđu. Jagodinska bolnica radi bez prekida već 147 godina i ubraja se $\mathrm{u}$ najstarije zdravstvene ustanove u Srbiji.

\section{ZAHVALNICA}

Ovu studiju je finansijski podržalo Ministarstvo prosvete, nauke i tehnološkog razvoja Republike Srbije, projekat br. 172026. 